\title{
Notes on Polish polypores 5. Synopsis of the genus Spongipellis
}

\author{
MARCIN PIATEK', DOMINIKA SETA' ${ }^{2}$ and ANDRZEJ SZCZEPKOWSKI \\ Department of Mycology, w. Szafer Institute of Botany, Polish Academy of Scicnces \\ Lubicz 46, PL-31-512 Kraków, mpiatek@ib-pan.krakow.pl \\ 'Department of Algology and Mycology, University of Lódź \\ Banacha 12/16, PL-90-237 Lódz, dominika@biol.uni.lodz.pl \\ Department of Mycology and Forest Phytopathology \\ Warsaw Agricultural University - SGGW \\ Nowoursynowska 166, PL-02-776 Warszawa, szczepkowski@ delta.sggw.waw.pl
}

Piątek M., Seta D., Szczepkowski A.: Notes on Polish polypores. 5. Synopsis of the genus Spongipellis. Acta Mycol, 39 (1): 25*32, 2004.

The paper deals with representatives of the genus Spongipellis Pat. in Poland. Spongipellis pachyodon (Pers.) Kotl. et Pouzar is reported for the first time from Poland and Belarus. Its basidiomes are described and illustrated, and taxonomy, ecology and distribution are reviewed. Two other species, $S$. delectans (Peck) Murrill and $S$. spumeus (Sowerby: $\mathrm{Fr}_{\mathrm{r}}$ ) Pat, are bricfly discussed. Distribution maps in Poland for each species are provided, an identification key to the species of Spongipelits in Poland is given, and basidiospore dimensions of each species are included based on studied materials.

Key words: polypores, Spongipellis delectans, S. pachyodon, S. spumetts, taxonomy, ecology, distribution in Poland

\section{INTRODUCTION}

This paper is continuation of studies devoted to taxonomy, ecology and chorology of polypores occurring in Poland. Previously several species new for this country have been reported and occurrence of many rarities has been discussed (c.g., $\mathrm{Piątek} 2001,2003 \mathrm{a}-\mathrm{c}$, in press; $\mathrm{P}$ iąt ek and $\mathrm{C}$ abała in press, and literature cited therein). Here we report another species new for Poland, viz. Spongipellis pachyodon (Pers.) Kotl. et Pouzar, and briefly discuss two other species from the genus Spongipellis Pat. known from the country. In addition, S. pachyodon is reported for the first time from Belarus.

The present study is based on herbarium materials preserved in KRAM, KRAMDomański, LOD and WAML. Abbreviations of herbaria follows Holmgren et al. (1990); the abbreviation WAML means Herbarium of Department of Mycology and Forest Phytopathology of the Warsaw Agricultural University - SGGW. For Spon- 
gipellis pachyodon we examined all materials from above mentioned herbaria, while for two other species we studied only materials from Poland. Observations, measurements and drawings of microscopic elements were made from slide preparations stained with solution of phloxine in $5 \% \mathrm{KOH}$ under the light microscope NIKON Eclipse E600 with Nomarski phase contrast. Thirty basidiospores per specimen were measured followed recommendation of Parmas to and Parmasto (1987). In the text the following abbreviations are used: $\mathrm{L}=$ mean spore length (arithmetical mean of all spores, in $\mu \mathrm{m}$ ), $\mathrm{W}=$ mean spore width (arithmetical mean of all spores, in $\mu \mathrm{m}), \mathrm{Q}=$ quotient of the mean spore length and the mean spore width ( $\mathrm{L} / \mathrm{W}$ ratio) (after Niemelä 1998). Measurements derive from basidiomes and none of them from spore prints. The measurements for each specimen are given in Tab. 1 .

Table 1

Basidiospore dimensions of specimens studies (all dimension in $\mu \mathrm{m}$ )

\begin{tabular}{|l|c|c|c|c|}
\hline \multicolumn{1}{|c|}{ Collections } & Dimensions of basidiospores & L & W & Q \\
\hline S. delectons & $6.0-7.5(-8.0) \times 4.0-5.0(-6.0)$ & 6.9 & 4.7 & 1.5 \\
\hline KRAM-Domański 546 & $5.5-6.0(-6.5) \times 4.5-5.0(-6.0)$ & 5.9 & 5.0 & 1.2 \\
\hline S. pachyodon & $5.0-6.0(-6.5) \times 4.5-5.0(-5.5)$ & 5.5 & 4.9 & 1.1 \\
KRAM F-54101 & $(5.5-) 6.0-7.0 \times 4.5-5.5(-6.0)$ & 6.4 & 5.1 & 1.2 \\
LOD 43218 (Wiaczyń reserve, 25 Aug. 2003) & $(6.0-) 6.5-7.0(-9.0) \times(4.0-) 4.5-5.0(-6.0)$ & 6.9 & 4.9 & 1.4 \\
KRAM-Domaniski 5974 & $6.0-8.5 \times 4.5-6.0$ & 7.3 & 5.2 & 1.4 \\
\hline S. spumieus & $6.0-7.0(-8.0) \times(4.5-) 5.0-6.5(-7.0)$ & 6.6 & 5.6 & 1.2 \\
KRAM-Domafíski 7122 & & & \\
WAML s.n. (Wicliszcw. 17 Sept. 2003) & & & \\
WAML s.n. (Warszawa, 23 Sept. 2003) &
\end{tabular}

\section{A NOTE ON SPONGIPELLIS}

The genus Spongipelilis, typitied by $S$. spumeus (Sowerby: Fr.) Pat., is representative of tyromycetoid polypores. It is characterized by white, pilcate or semiresupinate basidiomes, duplex consistency of context, monomitic hyphal system, with clamped hyphae, globose to broadly ellipsoid, thick-walled and cyanophilous basidiospores, and causing a white rot in wood. Its close relatives are genera Abortiponis Murrill, Climacocystis Kotl. et Pouzar, Oligoporus Bref. and Tyromyces P. Karst. (for details about these genera see Ryvarden 1991).

Abortiporus has similar duplex context, monomitic hyphal system, slightly thickwalled basidiospores, and causes white rot in wood. It differs from Spongipellis mainly by stipitate basidiomes. The type species of Abortiporus, A biennis (Bull.: Fr.) Singer has gloeocystidia which are absent in the generitype of Spongipellis, but this character is variably observed in other species of $A$ bortiporus.

Climacocystis has also context with duplex consistency, monomitic hyphal system, and causes white rot in wood, but it has thin-walled, ellipsoid basidiospores, and above all, characteristic cystidia, which are ventricose, acute and thick-walled towards the apex. Such cystidia are absent in Spongipellis, as well as in Abortiporus, Oligoporus and Tyromyces. 
Oligoporus has monomitic hyphal system, but the context is homogeneous, basidiospores are thin-walled, allantoid or ellipsoid and the species cause a brown rot in wood.

Tyronyces has similar white, sappy, pileate or semiresupinate basidiomes, mostly monomitic hyphal system (a few species have dimitic hyphal system), and causes white rot in wood, but it differs from Spongipellis by homogeneous context, and thinwalled, allantoid to ovoid basidiospores.

Nine species are currently accepted in the genus Spongipellis: $S$. caseosus (Pat.) Ryvarden, $S$. chubutensis J. E. Wright et J. R. Deschamps, $S$. cretaceus (Lloyd) Ryvarden, S. delectans (Peck) Murrill, S. malicola (Lloyd) Ginns, S. pachyodon, S. sibirica (Penzina et Ryvarden) Penzina et Kotir., S. spumeus and S. unicolor (Schwein.) Murrill. (Wright and Deschamps 1972; Ryvarden 1983, 1990; Ginns 1984; Gilbertson and Ryvarden 1987; Ryvarden and Gilbertson 1994; Kotiranta and Penzina 2001; Stalpers and Stegehuis 2004).
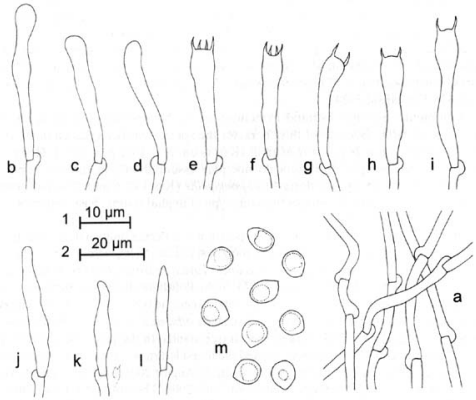

Fig. 1. Spongipelis pachyodon (Pers.) Kotl. et Pouzar (drawn from KRAM F-54101 by J. Cabała): a - generative hyphae, b-i - basidia, j-I - cystidioles, $m$ - basidiospores. Scale bars: 1 for $\mathrm{m}, 2$ for $\mathrm{a}-\mathrm{I}$. 


\section{TAXONOMIC DESCRIPTION}

Spongipellis pachyodon (Pers.) Kotl. et Pouzar, Ćeská Mykol. 19: 77. 1965.

Basidiomes annual, pileate to semiresupinate, broadly attached to the substrate, single or in imbricate groups, coriaceous in fresh conditions, hard when dry; pileus up to $5 \mathrm{~cm}$ long and $1 \mathrm{~cm}$ wide, upper surface white to cream or slightly ochraceous, azonate, finely tomentose when young but smooth in older specimens; hymenophore white when fresh, becoming ochraceous during drying, irpicoid near the margin, and strongly hydnoid in the most part of the area, teeth cylindrical, up to $10 \mathrm{~mm}$ long, in dry specimens covered by resinous substance; context white, up to $5 \mathrm{~mm}$ long, with weakly differentiated duplex consistency. Hyphal system monomitic, generative hyphae with clamps, hyaline, slightly thick-walled, in the context up to $5 \mu$ m wide, in the trama up to $2 \mu \mathrm{m}$ wide, agglutinated and with numerous oil drops; cystidia or gloeocystidia absent, cystidioles fusoid, with basal clamp, 30-40 $\times$ 4-6 $\mu \mathrm{m}$; basidia narrowly clavate, elongated at the base, with basal clamp and (2-)4 stcrigmata, 35-40 $\times 5-7 \mu \mathrm{m}$; basidiospores globose to broadly ellipsoid, hyaline, smooth, thick-walled, non amyloid, with oil drop, 5.5-6.0(-6.5) $\times$ 4.5-5.0(-6.0) $\mu \mathrm{m}$ (Fig. 1).

Specimens examined (selected). Poland. Niziny Środkowopolskie, Wzniesienia Lódzkie: Wiączyń reserve (Brzeziny forestry), forest division $170 \mathrm{c}$, mixed forest, on fallen trunk of Fagus sylvatica, 20 Nov. 2002, leg. D. Seta (KRAM F-54101, LOD 43217), 25 Aug. 2003, leg. D. Seta (LOD 43218); Belarus. Wysoczyzny Podlasko-Białoruskie, Równina Bielska: Białowieża Primeval Forest, forest division 807, oak forest, on fallen trunk of Quercus petraea, 23 Sept. 1969, leg. M. K. Michalewicz (KRAM-Domański 5974).

Comments. Strongly hydnoid hymenophore is characteristic feature for Spongipellis pachyodon. Because of this character the species has been placed in the past in a separate genus Irpiciporus Murrill (Kotlaba and Pouzar 1957). However, since the macroscopic characters do not play essential role in the taxonomy of polypores it was finally transferred to Spongipellis (Kotlaba and Pouzar 1965) with generitype of which it shares the same type of hyphal system, basidiospores, and duplex consistency of the cortex.

Spongipellis pachyodon has wide host spectrum, but occurs only on deciduous trees, both living and dead ones. The most common host in Europe is Quercus, but it was also collected on further trees: Ailanthus, Castanea, Fagus, Fraxinus, Juglans, Platanus and Salix (Ryvarden and Gilbertson 1994). In the Polish locality it was found on fallen trunk of Fagus sylvatica. Olaczek (1962) determined the type of forest in the Wiączyn reserve as mixed forest with Fagus sylvatica, Abies alba and Acer pseudopiaianus, with numerous fragments of 300 ycars old becch trec-stands. In the place where the trunk with basidiomes of $S$. pachyodon was found the forest is almost exclusively composed of beech trees. Since the first finding of the fungus in August 2001 it occurred regularly in the spring, summer and autumn months until July 2004 . Therefore, it is very probable that the fungus can survive in the reserve in the next years, but because this is the only locality in Poland it should be considered as threatened species, and probably included in the "CR" category in revised "red list" classification (IUCN 2001).

Spongipeilis pachyodon is an almost cosmopolitan species, widely distributed worldwide but rather rarely reported. Most localities are known from eastern United 
States and Canada (Gilbertson and Ryvarden 1987), and from Europe (Ryvarden and Gilbertson 1994). It occurs also in Africa: Morocco, Tanzania (Kotlaba 1984; Renvall and Niemelä 1993), Asia: Caucasus, India (Kotlaba 1984; Rattan 1977), Australia (May et al. 2003), and South America: Uruguay, Brazil (Gazzano 1998; Ryvarden and de Meijer 2002).

In Europe Spongipellis pachyodon is restricted mostly to southern and central part of the continent, the northernmost localities

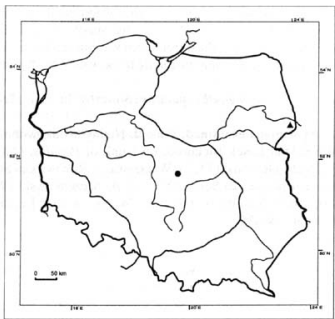

Fig. 2. Spongipelis pachyodon (-) and Spongipellis delectans $(\mathbf{\Lambda})$ in Poland. are in Denmark and southern Sweden. In this latter country it was known from one locality near Stockholm but now is probably extinct because it has not been rediscovered since 1913 (An o ny mous 2004). In their map Ryvarden and Gilbertson (1993) reported this species also from Poland but the source of their information is unknown. Hence, the finding published here (Fig. 2) is the first fully documented record of $S$ pachyodon in the country. This fungus is also for the first time reported from Belarus, where it was found in the Białowieża Primeval Forest. It is the second polypore, published recently, which is known from Belarusan part of this virgin forest and absent in Polish part. Previously Haploporus tuberculosus (Fr.) Niemelä et Y. C. Dai has been recorded based on specimen found in herbarium of late Professor Stanisław Domański (Piątek 2003d).

\section{BRIEF NOTES ON TWO OTHER SPECIES}

\section{Spongipellis delectans (Peck) Murrill, North Am, Flora 9: 38. 1907.}

Specimens examined. Poland. Wysoczyzny Podlasko-Białoruskic, Równina Bielska: Białowieża Primeval Forest, mixed forest, on fallen trunk of deciduous tree, 25 Oct. 1959, leg. S. Domański (KRAM-Domański 546), same location and habitat, on fallen trunk of Carpinus beiulus, 20 Oct. 1963, leg. S. Domański (KRAM-Domański 3442).

Comments. This species is known only from the virgin forest of the Białowieza National Park in NE Poland (Fig. 2). Dom a ński et al. (1967) mentioned only three collections of Spongipellis delectans, two from September 1956 and 1957 collected by Professor Henryk Orłoś and one from October 1963 found by Professor Stanisław Domański (cited above). In KRAM-Domański we located the fourth collection, determined previously as "Spongipellis litschauer Lohw." (cited above as No. 546). This 
name is however synonymous with $S$. delectans (Ryvarden and Gilbert son 1994). The specimen from this collection has smaller pores but microscopically matches well with the concept of the latter species: it has thick-walled, broadly ellipsoid to subglobose basidiospores and distinctly thick-walled hyphae in the context.

Spongipellis spumeus (Sowerby: Fr.) Pat., Ess. Tax.: 84. 1900.

Specimens examined. Poland. Niziny Środkowopolskic, Równina Warszawska: Warszawa, Lasek Bielański, on trunk of Populus, Oct. 1973, leg. P. Wierzchowski (KRAM-Domański 7122); Warszawa, at Rakowiecka Str., on trunk of living Populus x petrowskiana, 23 Sept. 2003, leg. A. Szczepkowski (WAML s.n.); Niziny Środkowopolskie, Kotlina Warszawska: Wieliszew near Legionowo, 17 Sept. 2003, leg. K. Felczak (WAML s.n.).

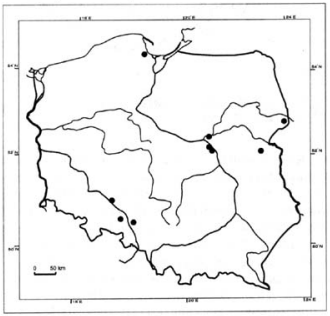

Fig. 3. Spongipelis spumeus in Poland.

Comments. Spongipellis spumeus is evidently a rare species in Poland, but the most common species within the genus Spongipellis. To our best knowledge it was found in the country nine times (Fig. 3). The oldest known localities are in the Lower Silesia: Wrocław-Osobowice, Kamień Śląski near Strzeloc Opolskie and Niemodlin (Schröter 1888). Further it was found near Manie in the neighbourhood of Międzyrzec Podlaski (Eichler 1900), in Kolibki near Orlowo (Teodorowicz 1936), in Białowieża (Domański et al. 1967), in Wieliszew near Legionowo and on two locations in Warszawa (this paper). The most common host for $S$. spumeus in Poland is Malus domestica, but single reports are also from Betula, Populus and Populus x petrowskiana. Populus $\mathrm{x}$ petrowskiana, reported here, is new host in Polish population of Spongipellis spumus. Malus domestica is also a host for similar macroscopically and more common Tyromyces fissilis (Berk. et M. A. Curtis) Donk (Piątek 1999). It can be easily distinguished from $S$. spumeus by homogeneous context, smaller basidiospores, presence of chlamydospores and changing colour to pinkish or pale umber after drying. 


\section{KEY TO THE GENUS SPONGIPELLIS IN POLAND}

The species of Spongipellis occurring in Poland and Europe may be identified using the key given below. The references in the key indicate where recent descriptions of the species can be found. Two references for each species are given: the first includes the monograph with description based on materials from outside of Poland, and the second includes the work with description based on Polish specimens.

1. Hymenophore distinctly hydnoid, basidiospores globose to broadly ellipsoid, $5.5-7.0 \times 4.5-5.5 \mu \mathrm{m}$

S. pachyodon

(Ryvarden and Gilberts on 1994: 645; this paper).

$1^{\prime \prime}$. Hymenophore poroid, or sometimes sinuous to dacdaleoid, basidiospores subglobose to broadly ellipsoid

2. Hymenophore circular, angular or deadaleoid, pores 1-2 per mm, contextual hyphae distinctly thick-walled, basidiospores subglobose to broadly ellipsoid, $6.0-7.5 \times 4.0-5.0 \mu \mathrm{m}$

S. delectans

(Ryvarden and Gilbertson 1994: 643; Domański et al. 1967:96, as $S$. bredecelensis).

$2^{n}$. Hymenophore circular, rather regular, pores 1-3 per mm, contextual hyphac thin-walled or slightly thick-walled, basidiospores subglobose to broadly ellipsoid, $6.0-8.5 \times 4.5-6.0 \mu \mathrm{m}$

S. spumeus

(Ryvarden and Gilbertson 1994: 646; Domański et al. 1967:95).

Acknowiedgements: We are grateful to Dr Jolanta Cabala for preparing the illustrations. This study was supported by the State Committee for Scientific Research (KBN), grant No. 2 PO4G 08026 and Univer. sity of tódž (505/411).

\section{REFERENCES}

A nonymous 2004 Polypores of Sweden. Checklist of species. <http:/www.algonet.se/ fungus/cheklist.humi>. Fungus info: Norrköping, Sweden.

Domański S. Orłos H., Skirgiełto A. 1967. Flora Polska. Grzyby (Mycota) 3: Polyporaceae pileatac. Mucronoporaceae pilcatac, Ganodermataceac, Bondarzewiaceac, Boletopsidaceac, Fistulinaceac. PWN, Warszawa.

Eichler B. 1900. Matcriały do flory grzybów okolic Międzyrzeca. Pamiętn. Fizjogr. 16: 157-206.

Gazzano S. 1998, Notas sobre Basidiomycetes xilofilos del Uruguay, VIII. Registro de Aphyllophorales y sus sustratos arbóreos. Comun. Bot. Mus. Hist. Nat. Montevideo 109 (6): 1-12.

Gilbertson R. L., Ryvarden L. 1987. North American polypores. 2. Megrasporoporia-Wrightoporia. Fungiflora, Oslo.

Ginns J. 1984. New names, new combinations and new synonymy in the Corticiaccac, Hymenochaetaceac and Polyporaceac. Mycotaxon 21: 325-333.

Holmgren P. K. Holmgren N. H. Barnett L. C. 1990. Index herbariorum. Part I: The herbaria of the world. Sth edition. Regnum Vegetabile 120: 1-693.

I U CN 2001. IUCN Red List Categories and Criteria: Version 3.1. IUCN Species Survival Commission. IUCN, Gland, Switzerland and Cambridge, $\mathrm{Pp}$, ii +30

Kotiranta H., Penzina T. 2001. Spongipellis sibince, comb. nova (Basidiomycetes), and its affinities to the polypore genera Tyronyces, Atrantioponis and Climacocystis. Ann. Bot. Fennici 38: 201-209.

Kotlaba F. 1984. Geographical distribution and ecology of polypores (Polyporales s. 1.) in Czechoslovakia. Academia. Praha (in Czech with English summary)

Kotlaba F. Pouzar Z. 1957. Poznámky k tî́dẻni evropských chorošü. Česká Mykol. 11(3): 152-170. Kotlaba F., Pouzar Z. 1965. Spongipelis litschateri Lohwag and Tyromyces kmetii (Bres) Bond et Sing.. two rare polypores in Czechoslovakia. Ceská Mykol. 19 (2): 69.78 (in Czech with English summary). 
May T. W., Milne J. Shingles S., Jones R. H. 2003. Fungi of Australia vol. 2b. Catalogue and bibliography of Australian fungi 2. Basidiomycota p.p. and Myxomycota. Csiro Publishing, Australian Biological Resources Study.

Niem ela T. 1998. The Skeletocutis subincamata complex (Basidiomycetes), a revision. Acta Bot. Fennica 161: 1-35.

Olacze k R. 1962. Rezerwat bukowy Wiączyñ. Zesz. Nauk. Uniw. Lódz., Nauki Mat.Przyr.. Scr. II 13: 93.107.

Parmasto E.. Parmasto 1. 1987. Variation of basidiospores in the Hymenomyeetes and its significance to their taxonomy. Biblioth. Mycol. 115: 1-168.

Piatek M. 1999. Tromyces fissilis (Fungi, Poriales) - its taxonomy, bionomics and distribution in Poland. Fragm. Florist. Geobot. Ser. Polonica 6: 189-197 (in Polish with English summary).

Piạtek M. 2001. The genus Anirodie'la (Fungi, Poriales) in Poland. Polish Bot. J. 46 (2): 183-190.

P i ąte k M. 2003a. Notes on Polish polypores. 1. Oligoponus alni, comb. nov. Polish Bot. J. 48 (1): 17-20. Piąte k M. 2003b. Notes on Polish polypores. 2 Oxyporus latemanginatus. Polish Bot. J. 48 (1): 63-68.

Piatek M. 2003c. Notes on Polish polypores. 3. Four rare species of old growth forests. Polish Bot. J. 48 (2): $1.31-144$

Piatek M. 2003d. Haplopons tuberculosus, a new polypore genus and species in Belarus, with a new combination in Haploportus. Polish Bot. J. 48 (1): $81-83$.

Piatek M. Notes on Polish polypores, 4. Polyporus alveoiaris. Karstenia 44 (in press).

Piątek M., Cabata J. New and noteworthy on polypores from Poland and validation of the family Phaeotrametaceae. Mycotaxon (in press).

Ratian S. S. 1977. The resupinate Aphyllophorales of the North Western Himalayas. J. Cramer, Vaduz.

Renvall P. Niemelia T. 1993. Ocotea usambarensis and its fungal decayers in natural stands. Bull. Jard. Bot. Nat. Belg. 62: 403-414.

Ryvarden L. 1983. Type-studies in the Polyporaceae 14. Species described by Patouillard, either alone or with other authors. Occas. Pap. Farlow Herb. 18: 1-39.

Ryvarden L. 1990. Type studies in the Polyporaceae 22. Species described by C. G. Loyd in Polyponus. Mycotaxon 38: 83-102.

Ryrarden L. 1991. Genera of polypores. Synopsis Fungorum 5: 1-363.

Ryvarden L., Gilbertson R. L. 1994. European polypores. 2. Meripilus-Tyromyces. Symopsis Fungorum $7: 389-74,3$.

Ryvarden L, de Meijer A. A. R. 2002. Studies in neotropical polypores 14. New species from the state of Paraná, Brazil. Synopsis Fungorum 15: 34-69.

Schröter J. 1888. Die Pilze Schlesiens. In: F. Cohn (ed.). Kryptogamen-Flora von Schlesien. 3. Band, 1. Halfte. J. U. Kern's Verlag. Breslau.

Stalpers J. A. Stege huis G. 2004. Aphyllophorales Database, <http:/ww.cbs.knaw.nl/databases/ indcx.htm>, Centraalbureau voor Schimmelcultures: Utrecht, Netherlands.

Teodorowicz E. 1936. Grzyby wyzsze polskiego wybrzeza. Bad. Przyr. w Toruniu 2: 1-65 (in Polish with German summary).

Wright J. E.. Deschamps J. R. 1972. Basidiomicetos xilófilos de los Bosques andinopatagónicos. Rev. Inv. Agrop. INTA. Serie 5. Pat. Veg. 9 (3); 111-196.

\section{Badania nad grzybami poliporoidalnymi w Polsce 5. Rodzaj Spongipellis}

\section{Streszczenic}

W artykule uwzgledniono grzyby z rodzaju Spongipellis Pat. występujące w Polsce. Spongipelis pachyodon (Pers.) Kotl. et Pouzar podano po raz pierwszy z Polski i Bialorusi. Owocniki tego gatunku szczególowo opisano i zilustrowano. Ponadto omówiono jego taksonomię, ckologię oraz rozmicszczenic gcograficzne. Krótko przedyskutowano także dwa dalsze gatunki znane z naszego kraju, mianowicie $S$. delecians (Peck) Murrill oraz S. spumens (Sowerby: Fr.) Pat. Rozmieszczenie każdego gatunku w Polsce przedstawiono na mapach, dołączono klucz do oznaczania wszystkich gatunków z rodzaju Spongipellis w Polsce oraz w oparciu o badane materialy zielnikowe podano wymiary zarodników dla każdego gatunku. 